\title{
Pengembangan Konstruksi Metodologi Hukum Islam bagi Perubahan Masyarakat Indonesia
}

\author{
Karimatul Ummah
}

\begin{abstract}
In facing the problem of more and more complex life, the Islamic law must be dynamic and actual in order that its role can be maximized both as a guidance controller of the change of society. In this condition, the effort of developing the methodological construction of Islamic Law is a must, but it uses the frame of its function.
\end{abstract}

\section{Pendahuluan}

Perkembangan tata kehidupan manusia baik sebagai individu maupun kelompok. senantiasa dibarengi dengan fenomena yang mengarah pada perubahan perilaku masyarakatnya. Demikian juga saat ini ketika. era milenium ketiga didengungkan, yang ditandai dengan era keterbukaan sebagai dampak perkembangan teknologi dan komunikasi, telah memunculkan sejumlah masalah kemanusiaan yang serius yang tentu saja akan membawa sikap perubahan pada perilaku masyarakat dan membutuhkan solusi yuridisnya. Masalah-masalah kemanusiaan yang timbul sebagai dampak dari adanya era keterbukaan tersebut diantaranya adalah masalah ekonomi dan keuangan terutama terhadap jasa bank yang menawarkan berbagai macam produknya, masalah kehidupan manusia yang cenderung individualistik, materialistik dan sekularistik. Hal ini nampak pada pola kehidupan yang hanya berkaca pada mode tanpa memperdulikan etika dan moral, serta masalah-masalah seputar isu pelanggaran hak asasi manusia. Tengoklah beberapa contoh eksploitasi anak dan wanita yang kurang pada tempatnya atas nama hak asasi manusia.

Dalam menghadapi problematika di atas masyarakat kemudian kini memusatkan perhatian pada peran dan fungsi hukum baik sebagai pengendali maupun sebagai pengontrol setiap perubahan yang terjadi dalam masyarakat.' Demikian halnya dengan keberadaan Hukum Islam di Indonesia, ketika

'Dalam filsafat hukum dikenal adanya dua fungsi hukum yaitu social control (alat pengawas masyarakat) konsep ini diperkenalkan oleh von Savigny dan social engineering (alat pengubah masyarakat) konsep ini berasal dari Rescoe Pound, Mukhtar Kusumaatmaja mengembangkannya di Indonesia dengan istilah perekayasa hukum. Lihat Lili Rasyidi dan B. Arief Sidharta, Filsafat Hukum Mazhab dan Refleksinya (Bandung: Remadja Karya, 1989), hlm 86, 106. 
dampak negatif dari adanya perubahan masyarakat makin membengkak maka peran dan fungsinya dipertanyakan mengingat hukum ini telah lama diakui keberadaannya sebagai hukum yang tumbuh dan berkembang di Indonesia baik secara materiil maupun formil. ${ }^{2}$ Keberadaan Hukum Islam secara formil tersebut dapat dilihat pada rumusan Hukum Indonesia yang tertuang dalam Undang-undang Nomor 14 Tahun 1970 tentang Ketentuan-ketentuan Pokok Kekuasaan Kehakiman yang menyebutkan bahwa Hakim sebagai penegak hukum dan keadilan wajib menggali, mengikuti, memahami nilai-nilai hukum yang hidup dalam masyarakat. Adapun yang dimaksud nilai-nilai yang hidup dalam masyarakat antara läin kebiasaan dan Hukum Islam.

Bertitik tolak dari peran dan fungsi hukum sebagaimana tersebut di atas, kiranya Hukum Islam haruslah senantiasa dinamis dan aktual agar muatan materi yang terkandung di dalamnya dapat diaplikasikan sebagai solusi untuk menyelesaikan masalah-masalah kontemporer yang makin variatif, terutama terhadap dampak negatif dari adanya perkembangan ilmu pengetahuan dan teknologi. Dalam kerangka inilah maka upaya untuk mengaktualkan Hukum Islam menjadi suatu keharusan baik mengenai materinya maupun metodologinya. Dengan demikian upaya untuk mengembangkan konstruksi metodologi Hukum Islam yang akan dijadikan dalil penetapan hukum menjadi keharusan untuk dilakukan.
Berangkat dari pemikiran tersebut, muncul pertanyaan: bagaimanakah konstruksi metodologi Hukum Islam, serta upaya dan peluang apakah yang mungkin dilakukan bagi pengembangannya agar Hukum Islam dapat dioptimalkan peranannya baik sebagai pengendali maupun pengontrol bagi perubahan masyarakat indoriesia?

\section{Hukum Islam: Antara Wahyu, Tuthan dan Pemikiran Manusia}

Hukum Islam diyakini oleh umat Islam sebagai hukum yang bersumber pada wahyu Allah. Keyakinan ini didasarkan pada kenyataan bahwa sumber utama Hukum Islam adalah Quran dan Hadits, sehingga Allah dan Rasul-Nya lazim disebut pencipta hukum. ${ }^{3}$ Meskipun demikian haruslah diakui bahwa Quran dan Hadits bukanlah kodifikasi hukum yang sempurna untuk bisa diterapkan dalam segala waktu dan peristiwa, sementara peristiwa yang dihadapi manusia makin berkembang dan variatif sejälan dengan perubahan masyarakat. Kenyataan tersebut tentulah menuntut peran aktif dari para ahli Hukum Islam untuk kreatif melakukan upaya penafsiran, penemuan dan penetapan hukum bagi pengembangan Hukum Islam sebagai dalilnya secara sistematis dan logis.

Upaya penafsiran, penemuan dan penetapan hukum tersebut dapat dilakukan dengan cara pemahaman terhadap kosa kata dan kalimat yang tertulis dalam Quran dan Hadits, dapat pula berupa upaya

\footnotetext{
2 Harun Nasution, "Dasar Pemikiran Pembaruan dalam Islam", dalam M. Yunan Yusuf dkk (ed), Cita dan Citra Muhammadiyah (Jakarta: Pustaka Panji Mas, 1985), hlm. 13

${ }^{3}$ Lahmuddin Nasution, Pembaruan Hukum /slam dalam Mazhab Syafii (Bandung: Remaja Rosdakarya, 2001), hlm. 7
} 
kontekstualisasi nilai-nilai yang terkandung dalam sumber utama Hukum Islam tersebut. Selain itu ahli Hukum Islam juga dapat melakukakn penggalian dan penemuan hukum yang berakar dalam masyarakat. ${ }^{4}$

Dari uraian di atas dapat diketahui bahwa Hukum Islam itu merupakan hukum yang jangkauannya amat luas meliputi syariah dan fikih. Syariah diartikan sebagai peraturan Allah yang disampaikan melalui nabi-Nya yang bersifat mutlak, sehingga keberadaannya tidak dapat diubah atau diganti karena berasal dari ajaran transendental yang murni, sedangkan fikih adalah pemahaman atau penafsiran terhadap ketentuan syariah baik secara tekstual maupun kontekstual. ${ }^{5}$

Dengan demikian Hukum Islam dalam kategori fikih yang notabene merupakan produk pemikiran manusia bukanlah sesuatu yang rigid terhadap perubahan, mengingat Hukum Islam ini harus mampu memberikan jawaban yuridis terhadap berbagai persoalan. Oleh karena itu peluang kajian Hukum Islam dalam konteks ini harus senantiasa terbuka dan harus dilakukan dengan memperhatikan implikasi-implikasi sosial dari penerapan produk-produk pemikiran hukumnya, selain itu harus pula tetap menjaga relevansinya dengan kehendak doktrin wahyu Allah tentang tingkah laku manusia.

\section{Konstitusi Metode Hukum Islam dan Pengembangannya}

Mencermati uraian yang terdapat pada pokok bahasan yang menyangkut pengertian Hukum Islam di atas, kiranya dapat diketahui bahwa pada intinya Hukum Islam itu bukanlah semata-mata hukum yang mutlak terdapat pada wahyu Allah semata melainkan juga norma-norma yang ditetapkan oleh ahli Hukum Islam dengan menggunakan metodemetode tertentu secara sistematis dan logis yang berakar dari Quran dan hadits.

Ketika Hukum Islam diartikan sebagai hasil dari pemikiran ahli Hukum Islam inilah terbuka peluang untuk mengaktualkannya sejalan dengan sifat dan karakter dari Hukum Islam itu yang adabtable. Ini berarti bahwa penetapan hukum dari para ahli Hukum Islam yang telah lampau harus senantiasa disesuaikan dengan waktu keadaan dan tempat. ${ }^{6} \mathrm{Hal}$ demikian untuk membuktikan bahwa Hukum Islam itu luas dan luwes.?

Penetapan hukum sebagaimana terpapar di atas sebenarnya telah dimulai sejak masa Rasulullah, akan tetapi penetapan hukum yang demikian ini kemudian menjadi Sunnah dan berkedudukan sebagai sumber Hukum Islam yang kuat setingkat di bawah Quran. Apa yang telah dilakukan oleh Rasulullah tersebut dalam pandangan Abdullah Mustafa al

${ }^{4}$ Fathurrahman Jamil, Filsafat Hukum Islam (Jakarta: Logos Wacana IImu, 1997), hlm. 13

5 lbid, hlm. 15

${ }^{6}$ Penetapan Hukum Islam dengan memperhatikan keadaan masyarakat tersebut dalam sejarah perkembangannya pernah dilakukan oleh Imam Syafi'idalam bentuk qaul qadim (pendapatlama) dan qauljadid (pendapat baru).

'Yusuf Qardlawi, 'Awamilu as-Sa'ah wa al Mununah fi asy-Syari'ah allslamiyah, Alih bahasa: Agil Husin al Munawwar, Keluasan dan Keluwesan Hukum Islam (Semarang: Dina Utama, 1993), him. 18 
Maraghi ${ }^{8}$ sebenarnya merupakan penetapan hukum yang telah menggunakan metodologi. Pernyataan tersebut diperkuat dengan argumennya bahwasanya Rasulullah seringkali menggunakan analogi dalam proses penyampaian Sunnah Qauliyah. Begitu pula peluang yang diberikan Rasulullah kepada para sahabatnya untuk menggunakan ra'yu ketika menyelesaikan permasalahan yang tidak diketemukan dasar hukumnya baik dalam Quran maupun Hadits, merupakan legalitas Syar'i yang dapat dijadikan dasar untuk mengembangkan Hukum Islam. Sebagai contoh peluang tersebut diberikan kepada Muad bin Jabal, Abu Musa al Asy'ari dan Ali bin Abi Thalib. Hanya saja peluang yang diberikan kepada Ali harus dilakukan dengan musyawarah dengan sahabat yang lain. ${ }^{9}$

Secara keseluruhan sebenamya dasardasar konstruksi metodologi Hukum Islam yang dipakai Rasulullah dapat diformulasikan dalam tiga pola; pertama, penjelasan yang berkaitan dengan arti dan maksud yang terkandung dalam Quran, seperti perintah salat yang masih umum dijelaskan dengan contoh perbuatan. Kedua, penjelasan yang berkaitan dengan perluasan dasar-dasar yang dinyatakan dalam Quran yang kelihatannya menambah hukum, seperti sabda Rasulullah yang menyatakan bahwa mahram (hal-hal yang dilarang atau diharamkan) karena susuan adalah sebagaimana mahram karena hubengan kekerabatan dalam hal perkawinan. Ini berarti memperluas makna mahram susuan. Ketiga, penjelasan yang berkaitan dengan pembatasan, pengurangan atau mempersempit makna yang terkandung dalam Quran. Hal ini seperti terlihat dari penjelasan Nabi yang menyatakan bahwa pembunuh tidak berhak atas harta warisan dari orang yang dibunuhnya. ${ }^{10}$

Pada masa Abu Bakar penetapan hukum yang dilakukan juga mengacu pada model analisis yang diterapkan Rasulullah, sebagaimana yang terjadi pada saat Abu Bakar ditanya tentang makna al kalalah yang terdapat dalam surat an-Nisa, beliau mengatakan, aku jawab menurut pemahamanku, al kalalah adalah seorang yang meninggal dan tidak meninggalkan anak serta orang tua. Abu Bakar juga berani menyamakan kedudukan kakek dengan ayah pada saat tidak ada ayah dalam masalah kewarisan, dan menjadi penghalang bagi saudara si-mayyit.

Kendati Abu Bakar telah melahirkan fatwa, tetapi di antara Khulafaur Rasyidin yang paling berani dan bervariasi dalam berfatwa adalah Umar bin Khattab. Secara umum konstruksi metodologi Hukum Islam pada masa Umar meliputi (1) pemahaman nash dalam konteks maqasid syariah atau tujuan Hukum Islam, (2) pemahaman nash sesuai dengan kemaslahatan umum, (3) pemahaman nash sesuai dengan dinamika masyarakat."

${ }^{8}$ Abdullah Mustafa al Maraghi, "al Fath al Mubin fi Thabaqat al Ushuliyyin", sebagaimana dikutip oleh Dede Rasyada, Hukum Islam dan Pranata Sosial (Jakarta: Raja Grafindo Persada, 1999), hlm. 119

${ }^{9} /$ bid, hlm.120

${ }^{10}$ Sidik Tono, Penafsiran hukum dalam proses perubahan sosial (al Mawarid: edisi VII Februari, 1999), hlm. 58

11 Dede Rasyada, op.cit, him 121 
Di antara contoh-contoh hasil ijtihad Umar sebagai hasil pendekatan dengan metodologi di atas adalah fatwanya tentang sejumlah orang yang melakukan pembunuhan secara berkelompok harus diqishas semuanya meskipun yang mereka bunuh hanya satu orang. Fatwa ini mendasarkan pada pertimbangan Hukum Islam yakni pemeliharaan jiwa manusia. Selain itu fatwanya tentang rampasan perang yang berupa harta yang tidak bergerak seperti tanah tidak harus dibagi-bagi kepada para prajurit perang tersebut tetapi diserahkan pada masyarakat daerah prajurit perang agar kemasiahatan mereka tetap terpelihara. Fatwa ini dikeluarkan sehubungan dengan tuntutan para prajurit atas tanah subur di lraq yang baru mereka taklukkan.

Pada kesempatan lain Umar juga bersikap keras terhadap dua orang muallaf, Uyainah bin Husein dan al Aqra bin Habis yang selalu mendapat santunan harta zakat pada masa Nabi dan Abu Bakar. Umar menolak memberikan zakat pada mereka karena menurutnya umat Islam sudak cukup kuat, tanpa harus menyantuni para muallaf. Dalam konteks ini penetapan hukum yang dilakukan Umar adalah mendasarkan pada dinamika masyarakat yang mempengaruhi dalam aplikasi pemahaman nash.

Tradisi penetapan hukum yang demikian itu berkembang hingga masa Tabi'in. Bahkan masa ini lahir tokoh besar bernama Ibrahim al Nakhai seorang fakih Islam yang mengajarkan ilmu fikihnya kepada Hamad bin Abi Sulaiman, yang kemudian menjadi guru Abu Hanifah, tokoh fikih rasional iraq. ${ }^{12}$

Kendati Imam Abu Hanifah banyak mengeluarkan fatwa hukum yang bervariasi, akan tetapi pola kajian metodologinya belum tersusun secara sistematis, sehingga para pengikutnya hanya mempelajari pada produk fikihnya. Langkah penyusunan konstruksi metodologi Hukum Islam secara sistematis baru dimulai oleh murid beliau Abu Yusuf dengan karyanya Kitab al Kharaj, kendati dalam karyanya ini Abu Yusuf belum menyusun teori-teori metodologi Hukum Islam secara menyeluruh dan baru terfokus pada perbedaan-perbedaan para ulama dalam kajian fikih rasionalnya. Oleh karena itu Abdul Wahhab Khallaf menyatakan bahwa orang yang pertama kali menyusun konstruksi metodologi secara menyeluruh adalah muhammad bin Idris al-Syafi'i melalui karya besarnya al Risalah. ${ }^{13}$

Konstruksi metodologi Hukum Islam secara garis besar tersusun dalam tiga pola, (1) pola bayani atau kajian semantik, (2) pola ta'lili atau penentuan illat hukum, (3) pola istislahiatau pertimbangan kemaslahatan atau kepentingan masyarakat. ${ }^{14}$ Pola pertama, menekankan pada kajian bahasa (semantik) yaitu suatu kajian yang menitik beratkan pada kajian kebahasaan yang ada dalam Quran dan Hadits. Hal ini dimaksudkan agar ketentuanketentuan dalam sumber utama Hukum Islam tersebut dapat dipahami mengingat seorang rasul diutus untuk menggunakan bahasanya sendiri, sebagaimana firman Allah dalam surat

${ }^{12}$ lbid, hlm. 122
${ }^{13}$ Abdul Wahhab khallaf, Ilmu Ushul Fikih (Semarang: Dina Utama, 1994), hlm. 85
${ }^{14}$ Ari Anshar, "Fikih Indonesia dalam Tantangan" sebagaimana dikutip oleh Sidik Tono dalam op.cit, hlm. 59 
Ibrahim, Kami tidak mengutus seorang rasulpun melainkan dengan bahasa kaumnya supaya ia dapat memberikan penjelasan dengan terang kepada mereka. Kajian yang menekankan pada aspek kebahasaan ini meliputi apakah lafad yang ada itu bermakna hakiki (sebenarnya) ataukah majazi (kiasan), bagaimanakah memilih kata musytarak (kata yang mempunyai arti lebih dari satu), bagaimana mengartikan perintah itu bermakna wajib untuk dikerjakan dan bukan sunnah, serta kata larangan bermakna haram dikerjakan dan bukan makruh.

Kedua, pola ta'lili yaitu suatu kajian yang menekankan pada aspek illat hukum atau alasan-alasan penetapan hukum. Kajian ini menjadi penting untuk dilakukan mengingat tidak dimungkinkannya ada aturan hukum yang tidak dibarengi dengan illatnya sebagaimana ungkapan kaidah fikhiyah bahwa hukum berkisar bersama illatnya, jika hukum ada maka illatpun ada, dan jika illat tidak ada maka hukumpun tidak ada. Keberadaan illat hukum dalam suatu ketentuan hukum kadang dapat diketahui dengan jelas, tetapi terkadang harus diupayakan mencarinya. Terkadang berada dalam satu ayat, tetapi terkadang berada dalam ayat lain. Ketika illat hukum tidak diketahui secara pasti maka ahli Hukum Islam mempunyai kewajiban untuk mencarinya. ${ }^{15}$
Pola ketiga adalah pola Istislahi. yaitu suatu kajian yang menitik beratkan pada pertimbangan kepentingan masyarakat. Kajian ini penting untuk dilakukan mengingat Hukum Islam ditegakkan karena adanya kepentingan yang akan dilindungi oleh hukum terutama adalah kepentingan masyarakat atau dalam wacana Islam dikenal dengan kemaslahatan. Kemaslahatan yang menjadi tujuan dari Hukum Islam itu meliputi maslahah dloruriyah (kepentingan pokok), maslahah hajjiyah (kepentingan sekunder) dan maslahah tahsiniyah (kepentingan tersier). Kemaslahatan yang dloruriyah ini dalam pandangan Syatibi ${ }^{16}$ meliputi kepentingan agama, harta, jiwa, keturunan dam harta.

Konstruksi metodologi Hukum Islam yang ditawarkan oleh Syafi'i tersebut pada prinsipnya bisa diterima oleh berbagai kalangan mazhab, hanya saja pada kajian istislahi menggunakan wadah yang berbeda yang pada prinsipnya tetap menekankan pada aspek kemaslahatan, misalnya Ulama Hanabilah menggunakan kata Istislah, sedangkan Ulama Malikiyah menggunakan istilah Maslahah Mursalah. ${ }^{17}$

Pola konstruksi sebagaimana terurai di atas dalam perjalanannya mengalami banyak perkembangan yang kesemuanya masih dalam kerangka menjunjung tinggi tujuan Hukum Islam, yang berbeda hanyalah pada aspek pendekatannya. Perkembangan yang

${ }^{15}$ Ahmad Azhar Basyir, Pokok-pokok Persoalan Filsafat Hukum Islam (Yogyakarta: Bagian Penerbitan dan perpustakaan Fakultas Hukum UII), 1984, hlm.16

${ }^{16}$ Wael B. Hallq, Sejarah Teori Hukum/slam (Jakarta: Raja Grafindo Persada, 2000), hlm. 247

${ }^{17}$ /stislah berarti mencari kemaslahatan atau kebaikan, sedangkan maslahah mursalah berari kemaslahatankemaslahatan yang menjadi dasar pertimbangan dalam pengkajian hukum untuk persoalan-persoalan yang tidak dinyatakan dalam nash. Dengan demikian perbedaan istilah ini tidak membawa perbedaan konotasi. Lihat Abdul wahhab Khallaf, Kaidah-kaidah Hukum Islam (Jakarta: Raja Grafindo Persada, 1994), hlm. 86. 
dimaksudkan antara lain berupa metode Istihsan yang dikembangkan oleh Ulama Hanafiyah, yaitu suatu metode penetapan dan penemuan Hukum Islam dengan cara beralih dari suatu ketetapan Qiyas pada hasil qiyas yag lain yang lebih kuat, atau dengan kata lain mentahsis qiyas dengan dali yang lebih kuat. Dengan demikian kajian istihsan ini sebenarnya masih berada dalam ruang lingkup kajian qiyas yaitu suatu metode yang menghubungkan sesuatu yang belum dinyatakan ketentuan hukumnya oleh nash kepada suatu yang sudah dinyatakan ketentuan hukumnya oleh nash karena keduanya memiliki kesamaan illat hukum.

Pengembangan konstruksi metodologi Hukum Islam yang lain adalah al-Dzari'ah. Menurut istilah al-dzari'ah diartikan sesuatu yang akan membawa pada perbuatan yang terlarang dan menimbulkan mafsadah atau sesuatu yang akan membawa kepada perbuatan yang baik dan menimbulkan manfaat. Sesuai dengan pengertian tersebut al-dzari'ah terbagi dua, (1) hal-hal yang akan membawa pada perbuatan terlarang dan menimbulkan mafsadah. Al-dzari'ah jenis pertama ini termasuk perbuatan buruk yang harus ditutup yang disebut sad al dzari'ah. Penutupan yuridis terhadap perbuatanperbuatan tersebut bisa dengan hukum haram atau makruh, tergantung bobot mafsadah yang akan ditimbulkannya. Contoh dari sad al dzari'ah adalah suatu kegiatan atau tindakan yang mengarah atau menimbulkan rangsangan untuk melakukan perbuatan zina, baik melalui hayalan, gerakan atau yang lainnya harus dilarang karena kesemuanya ini masuk dalam kategori mendekati zina. (2) halhal yang akan membawa pada perbuatan baik serta menimbulkan manfaat, dan oleh karena itu harus diupayakan kesempatan untuk melakukannya bisa dengan kerangka hukum yang wajib atau sunnah, tergantung pada bobot manfaat yang akan ditimbulkannya, inilah yang disebut fath al dzari'ah. Contohnya pengaturan pemberangkatan jemaah haji sebagai suatu kebijakan pemerintah terhadap terselenggaranya ibadah haji sebagai rukun Islam kelima. Ulama yang banyak melakukan pembahasan hukum dengan metode ini adalah ulama Malikiyah dan Hanabilah.

Istishab merupakan bentuk pengembangan konstruksi metodologi Hukum Islam yang banyak dilakukan oleh Ulama Syafi'iyah, Hanabilah dan Dhohiry. Istishab bermakna menetapkan hukum dengan tetap memberlakukan hukum yang ada untuk saat ini dan yang akan datang sesuai hukum yang berlaku pada waktu sebelumnya sampai ditemukannya dalil yang mengubahnya. Argumentasi logika pendukung metode ini adalah ${ }^{18}$ (a) bahwa ketentuan hukum yang telah ditetapkan sebelumnya baik oleh nash maupun kajian pemuan hukum secara logika tetap berlaku sebelum ada yang mengubahnya, karena tidak mungkin ada kefakuman dalam hukum. (b) Sebagai perbandingan logika adalah ikatan suami istri tetap berjalan sebelum ada tindakan yang membatalkannya, atau seseorang tetap dianggap berwudlu sebelum ada hal-hal yang membatalkannya.

Bentuk pengembangan konstruksi metodologi Hukum Islam yang paling

${ }^{18}$ Dede Rosyada, op.cit, him. 61 
menonjol adalah keberanian para ahli Hukum Islam untuk melakukan pendekatan terhadap kebiasaan masyarakat setempat dimana Hukum Islam itu tumbuh dan berkembang. Dalam wacana Islam terobosan pendekatan ini disebut al Urf. Dari konstruksi metodologi Hukum Islam inilah pada akhirnya dihasilkan suatu kaidah fikhiyah al adat al muhakkamah, yang artinya kebiasaan masyarakat dapat dijadikan rujukan dalam pembahasan Hukum Islam. ${ }^{19}$ Ulama Syafi'iyah menempatkan kebiasaan masyarakat ini dalam posisi yang penting dalam penetapan dan penemuan hukum terutama pada masalah-masalah yang tidak ada aturannya dalam Quran maupun Hadits. ${ }^{20}$

\section{Pengembangan Metodologi Hukum Islam sebagai Solusi Yuridis}

Sebagaimana diuraikan pada pembahasan terdahulu bahwa masyarakat senantiasa mengalami perubahan. Demikian juga dengan masyarakat Indonesia yang mengalami perubahan pada tatanan sosial, budaya dan ekonomi sebagai dampak kemajuan ilmu pengetahuan dan teknologi. Hal ini nampak jelas pada sikap, perilaku dan pola pikir masyarakat yang sangat fundamental. Sebagai gambaran perubahan ini adalah sesuatu yang dulu dianggap tabu kini dianggap sebagai sesuatu yang wajar.

Apabila keadaan ini dikaitkan dengan keberadaan Hukum Islam sebagai salah satu siatem yang turut mengendalikan dan mengontrol setiap perubahan yang torjadi, timbul suatu pertanyaan mampukah Hukum Islam menghadapinya? Di sinilah peran aktif dari ahli Hukum Islam dituntut untuk senantiasa mengembangkan kreativitasnya untuk senantiasa menggali, menetapkan dan menemukan hukum sebagai solusi untuk menyelesaikan persoalan-persoalan kontemporer yang makin berkembang dan variatif. Dalam wacana Islam upaya tersebut dikenal dengan nama ijtihad.

Berkenaan dengan keadaan tersebut haruslah diakui bahwa pada masa sekarang ada beberapa masalah yang muncul secara kebetulan mirip atau bahkan sama dengan beberapa persoalan yang dulu pernah dibahas oleh para ahli Hukum Islam terdahulu, meskipun demikian para ahli hukum Islam tersebut tetap berkewajiban untuk mempelajari dan meninjau kembali masalahmasalah yang telah ditetapkan hukumnya untuk kemudian menyesuaikannya dengan kondisi dan kebutuhan sekarang. Hal ini kemudian melahirkan kaidah fikiyah al muhafadhah ala al qadim al sholih wa al ahdzu bi al jadid al aslah, yang artinya mempertahankan yang lama yang baik dan mengambil yang baru yang lebih baik. ${ }^{21}$ Sedangkan mengenai masalah-masalah yang sama sekali baru ahli hukum sekarang harus menyelesaikannya dengan cara memahami secara baik terhadap masalah yang dimaksud dengan membahasnya secara seksama dengan tetap merujuk pada jiwa Hukum Islam yang terkandung dalam Quran

\footnotetext{
${ }^{19}$ Abdul wahhab Khallaf, op.cit, hlm. 123

${ }^{20}$ Lahmuddin Nasution, op.cit, hIm. 157

${ }^{21}$ Mun'im A. Sirry, Sejarah Fikih /slam Sebuah Pengantar(Yogyakarta: Pustaka Pelajar, 1995), hlm. 155
} 
dan Hadits.

Berkaitan dengan keadaan tersebut, maka ijtihad pada masa sekarang dapat dilakukan dengan 2 cara, (1) litihad Intiqa'i atau litihad Tariihi (2) litihad Insya'i atau litithad Ibtida'i.,22 ljtihad intiqa'i atau ijtihad tarjihi adalah ijtihad yang dilakukan seseorang atau sekelompok orang untuk memilih pendapat para ahli Hukum Istam terdahulu mengenai masalah-masalah tertentu sebagaimana tertulis dalam berbagai kitab fikih, kemudian menyeleksi mana yang lebih kuat dalilinya dan lebih relevan dengan kondisi sekarang. Jika para ahli Hukum Islam terdahulu berbeda pendapat maka akan diseleksi dengan cara mempertimbangkan argumentasinya, kemudian memberikan preferensinya terhadap pendapat yang dianggap kuat dan dapat diterima. ljthad jenis pertama ini disebut juga dengan ijtihad selektif.

Dalam melakukan ijtihad ini ada beberapa faktor yang penting untuk diperhatikan yakni adanya perubahan sosial budaya, kemajuan ilmu pengetahuan dan teknologi serta kesesuaiannya dengan tuntutan zaman. Faktor-faktor tersebut dapat dijadikan sebagai bahan pertimbangan dalam menyelesaikan masalah yang akan ditetapkan hukumnya. Dengan demikian dalam melakukan ijthad ini ahli Hukum Islam dituntut untuk melakukan analisis secara cermat terhadap masalah yang sedang dikaji. Analisis tersebut tidak terbatas pada dalil dan argumentasi yang dikemukakan oleh ahli Hukum Islam terdahulu tetapi juga harus melihat relevansinya dengan masa sekarang.
Sebagai ilustrasi contoh penerapan ijtihad ini akan dikemukakan masalah yang berhubungan dengan talaq atau perceraian. Menurut mayoritas ahli Hukum Islam termasuk mazhab empat, talak dinyatakan jatuh apabila diucapkan oleh suami kepada istri dalam keadaan sadar dan atas kehendak sendiri tanpa tergantung adanya saksi, akan tetapi menurut ahli Hukum Islam kalangan syi'ah talaq baru dianggap terjadi apabila disaksikan oleh dua orang saksi yang adil. Agaknya untuk masa sekarang pendapat Syi'ah dengan segala modifikasinya lebih dapat diterima.

Di Indonesia berdasarkan UndangUndang Nomor 1 Tahun 1974 tentang Perkawinan dan Pasal 123 Kompilasi Hukum Islam, talaq baru dianggap terjadi apabila dilakukan di depan sidang Pengadilan Agama. Ketentuan ini sejalan dengan disyariatkan talaq yang merupakan jalan terakhir untuk menyelesaikan persoalan suami istri, meskipun Rasulullah pernah bersabda bahwa talaq merupakan perbuatan halal tetapi sangat dibenci oleh Allah.

Itihad insya'i adalah usaha untuk menetapkan kesimpulan hukum mengenai peristiwa-peristiwa baru yang belum diselesaikan oleh ahli Hukum Islam terdahulu. Dalam melakukan ijtihad ini diperlukan pemahaman yang menyeluruh terhadap peristiwa baru. tersebut dari berbagai sudut pandang, di samping pengetahuan yang menjadi persyaratan ijtihad itu sendiri. Oleh karena itu dalam menggunakan media ijthad ini maka ijthad kolektif mutlak diperlukan karena keterbatasan pengetahuan seseorang.

22 Pengelompokan ijthad ini dikemukakan oleh Yusuf Qardlawi sebagaimana dikutip oleh Fathurrahman Jamil: op.cit. hlm 166 
Dengan demikian syarat menjadi mujtahid dalam ijtihad ini tidaklah dimiliki secara individual oleh seorang saja melainkan oleh beberapa orang sesuai dengan disiplin ilmunya. ${ }^{23}$ Sebagai contoh pada kasus penetapan hukum pencangkokan organ tubuh manusia harus terlebih dahulu didengar pendapat ahli di bidang kedokteran khususnya ahli bedah. Dari pendapat tersebut akan diperoleh informasi mengenai tata cara dan mekanisme pencangkokan organ tubuh manusia.

Dalam melakukan ijtihad insya'i ini seorang ahli Hukum Islam harus mengenal dengan baik konstruksi metodologi penetapan Hukum Islam di antaranya qiyas, istihsan, istisiah, istishab, al dari'ah dan urf sebagaimana telah dipaparkan terdahulu. Selain itu juga harus mengetaui tujuan disyari'atkannya Hukum Islam karena pada dasarnya semua metode penetapan Hukum Islam bermuara pada tujuan Hukum Islam (maqasid al syari'ah). ljtihad jenis kedua ini dikenal juga dengan istilah ijtihad kreatif, karena ahli Hukum Islam melakukan kajian hukum dengan menelaah karakter persoalan yang dihadapinya, melihat posisinya dalam kehidupan sosial, dalil-dalil yang dapat dijadikan rujukan dalam penetapan hukum serta mempertimbangkan akibat yang akan ditimbulkannya sehubungan dengan adanya penetapan hukum tersebut.

Dalam realitasnya di Indonesia kegiatan penetapan, penggalian dan penemuan Hukum Islam telah pula dilakukan upaya pengembangan konstruksi metodologi
Hukum Islam, bahkan ahli Hukum Islam di Indonesia juga telah berani melakukan pengembangan dengan berbagai macam pendekatan, antara lain dengan melakukan pengkompromian dengan Hukum Barat. Pengkompromian Hukum Islam dengan Hukum Barat ini pada masa dahulu nampaknya mustahil dilakukan pada kajiankajian Hukum Islam tradisional. Sebagai contoh dari upaya penkompromian dengan Hukum Barat ini adalah ketentuan yang terdapat pada Pasal 185 Kompilasi Hukum Islam tentang penggantian kedudukan ahli waris (plaatsvervoelling) meskipun dilakukan dengan beberapa modifikasi.

Kiranya dengan adanya kesadaran penuh dari para ahli Hukum Islam akan sifat keluasan dan keluwesan Hukum Islam itu di masa mendatang tidak diketemukan lagi perbedaan-perbedaan yang signifikan dalam mensikapi permasalahan yang ditimbulkan akibat perkembangan teknologi dan. perkembangan perubahan masyarakat. Kiranya pula tidak ada lagi kontroversi tentang goyang ngebor ataupun goyang patah-patah jika sad al dzariah dioptimalkan pendayagunaannya. Begitupun penetapan hukum terhadap masalah kontemporer tidak saja menjadi kewajiban pemerintah saja melalui lembaga formalnya yang bernama Majlis Ulama Indonesia dengan produk putusannya yang bernama "fatwa MUI", melainkan juga penetapan, penggalian dan penemuan hukum hendaknya senantiasa didengungkan secara lantang oleh lembagalembaga informal. Bukankah di indonesia

${ }^{23}$ llyas Supena dan M. Fauzi, Dekonstruksi dan Rekonstruksi Hukum Islam (Yogyakarta: Gama Media, 2002), hlm. 157 
organisasi masyarakat yang tidak hanya satu itu mempunyai lembaga penkajian dan penemuan hukum terhadap masalahmasalah kontemporer, semisal Lajnah Bahsul Masa'il NU dan Lajnah Majlis Tarjih Muhammadiyah. ${ }^{24}$

Dengan melihat realitas tersebut kiranya upaya-upaya untuk mengembangkan konstruksi metodologi Hukum Islam harus senantiasa dilakukan oleh para ahli Hukum Islam Indonesia agar setiap perubahan yang terjadi dalam masyarakat dapat dicari solusi yuridisnya dengan menggunakan Hukum Islam, sekaligus juga untuk membuktikan bahwa Hukum Islam bukanlah hukum yang kaku yang senantiasa mengalami ketertinggalan dalam memainkan peranannya baik sebagai pengendali maupun pengontrol perubahan masyarakat.

\section{Simpulan}

Berdasarkan pada uraian yang telah dipaparkan di atas, kiranya dapat disimpulkan sebagai berikut: bahwa konstruksi metodologi Hukum Islam secara garis besar tersusun dalam tiga pola yaitu pola bayani atau kajian semantik kebahasaan, pola ta'lili atau penentuan illat hukum dan pola tahsini atau pertimbangan kemaslahatan. Pengembangan konstruksi metodologi juga dilakukan oleh para ahli Hukum Islam di Indonesia sebagai solusi yuridis terhadap perubahan masyarakat dengan tetap menggunakan kerangka kemaslahatan, bahkan tidak saja tumbuh keberanian untuk melakukan pengkompromian antara Hukum Islam dengan hukum adat melainkan juga dengan hukum barat. Peluang untuk melakukan pengembangan konstruksi metodologi Hukum Islam tidak saja terbuka bagi lembaga formal bentukan pemerintah melainkan juga oleh lembaga informal organisasi masyarakat.

\section{Daftar Pustaka}

Basyir, Ahmad Azhar, Pokok-pokok Persoalan Filsafat Hukum Islam, Yogyakarta:

Bagian Penerbitan dan perpustakaan Fakultas Hukum UIII, 1984.

Hallq, Wael B., Sejarah Teori Hukum Islam, Jakarta: Raja Grafindo Persạda,

Jamil, Fathurrahman, Filsafat Hukum Islam, Jakarta: Logos Wacana IImu, 1997.

Ka'bah, Rifyal, Hukum Islam di Indonesia Perspektif Muhammadiyah dan NU, Jakarta: Universitas Yarsi, 1999.

Khallaf, Abdul Wahhab, ilmu ushul fikih, Semarang: Dina Utama, 1994,

Khallaf, Abdul Wahhab, Kaidah-kaidah Hukum Islam, Jakarta: Raja Grafindo Persada, 1994،

Nasution, Harun, Dasar Pemikiran Pembaruan dalam Islam, dalam M. Yunan Yusuf dkk (ed), Cita dan Citra Muhammadiyah, Jakarta: Pustaka Panji Mas, 1985.

Nasution, Lahmuddin, Pembaruan Hukum islam dalam Mazhab Syafii, Bandung: Remaja Rosdakarya, 2000.

Qardlawi, Yusuf, 'Awamilu As Sa'ah wa al

${ }^{24}$ Rifyal Ka'bah, Hukum Islam di Indonesia Perspektif Muhammadiyah dan NU (Jakarta: Universitas Yarsi, 1999), hlm. 132 
Murunah fi Asy Syari'ah al Islamiyah, Alih bahasa: Agil Husin al Munawwar, Keluasan dan Keluwesan Hukum Islam, Semarang: Dina Utama, 1993.

Rasyada, Dede, Hukum Islam dan Pranata Sosial,Jakarta: Raja Grafindo Persada, 1999.

Rasyidi, Lili dan B. Arief Sidharta, Filsafat Hukum Mazhab dan Refleksinya, Bandung: Remadja Karya, 1989.
Simy, Mun'im A., Sejarah Fikih Islam Sebuah Pengantar, Yogyakarta: Pustaka Pelajar, 1995.

Supena, Ilyas dan M. Fauzi, Dekonstruksi dan Rekonstruksi Hukum Islam, Yogyakarta: Gama Media, 2002.

Tono, Sidik, Penafsiran hukum dalam proses perubahan sosial, al Mawarid, edisi VII pebruari 1999. 